\title{
Luovien ja innovatiivisten tiimien rakentamista pk-yrityksessä
}

\author{
Hyvin toimivalla tiimillä voidaan löytää luovia ja innovatiivisia \\ ratkaisuja sekä tukea yrityksen henkilökunnan jaksamista antamal- \\ la heille mahdollisuuksia uusiin haasteellisiin tehtäviin. Turun opet- \\ tajankoulutuslaitos on toteuttanut ESR-rahoituksen turvin omaa \\ osaamistaan pk-yritysmaailmassa tukemalla yrityksen tarpeiden \\ mukaan muodostuvien tiimien rakentamisprosessia.
}

Turun opettajankoulutuslaitoksessa on toteutettu voimakkaan kehitysprosessin tuloksena ns. muutosagentti-koulutusta syksystä 1992 lähtien. K oulutusohjelmaa rakennettaessa aikaisempi koulutus kyseenalaistettiin. Suunniteltiin tuolloin syntyneitä tavoitteita tukevia sisältö- ja prosessistrategioita. (ks. lähemmin Heikkilä 1994) E räänä opetusmuotona aloitettiin tiimiopinnot, joiden tavoitteena oli rakentaa opiskelijoista heidän erilaisuuttaan hyväksikäyttäviä tiimejä.

O petusministeriö kannusti syksyllä 1996 ylio pistoja ja korkeakouluja levittämään tietotaitoaan pk-sektorille ja näin tukemaan suomalaista yritystoimintaa. Turun opettajakoulutuslaitos sai tätä tarkoitusta varten rahoitusta E uroopan sosiaalirahastosta, jonka tavoitteena oli tukea yrityksiä sopeuttamaan henkilökuntaansa elinkeinoelämän rakenne- ja tuotantojärjestelmien muutokseen kehittämällä osaamis- ja innovaatiorakenteita ( ESR-rahoitus 4.3.2.).

Turun opettajankoulutuslaitoksella haluttiin avautua ympäröivään yhteiskuntaan ja käyttää laitoksen osaamista, tiimiteorian tuntemista ja opettamisen kokemusta lähiseudun pk-yritystoiminnan tukemiseen. Turun kauppakamarin myötävaikutuksella löytyi neljä yritystä, joiden johto oli kiinnostunut hankkeesta. Y ritysten kanssa laadittiin projektille yhteinen arvopohja ja tavoitteet. $\mathrm{N}$ äin jo rahoitusta haettaessa projekti rakennettiin yrityksen tarpeille ja toiveille. Turun opettajankoulutuslaitos pyrkii omalla osaamisellaan tukemaan tiimien rakentamisprosessia sekä tiimissä toimivien henkilöiden omaa inmisenä kasvun mahdollisuutta. Y ritysten erilaiset toimintakulttuurit ja niiden tarjoamat mahdollisuudet ovat tehneet projektista jo alusta alkaen hyvin moniulotteisen.

\section{Projektin tavoitteet ja toiminta}

Projektin tarkoituksena on

- avustaa pk-yrityksissä luovien ja innovatiivisten tiimien rakentamisessa

- tukea henkilöstöä tiimissä tarvittavien taitojen omaksumisessa

- tukea yrityksissä yksilöiden persoonallista kasvua

- tukea yritysten johtamis- ja toimintakulttuurin kehittymistä dynaamiseksi oppivaksi organisaatioksi.

Lisäksi projektin avulla pyritään tukemaan yritysten sisäistä ja niiden välistä verkostoitumista, kehittämään yritystoimintaa hyödyntäviä uusia koulutusmalleja sekä hyödyntämään projektista saatuja yritysten reaalitodellisuuden kokemuksia opettajankoulutuksessa. 
Creatiimi-projekti tukee yrityksiä tiimien rakentamisprosessissa siten, että erilaisuutta rakentavasti hyväksikäyttäen pystytään luoviin ja innovatiivisiin ratkaisuihin. Projekti toteutuu erilaisten koulutusten ja yrityskohtaisten konsultaatioiden avulla. K aikille yrityksille yhteiset seminaarit rakentuvat teoreettisten lähtökohtien tarkasteluun professori Jorma Heikkilän johdolla ja perustuen teoksessa Innovatiivisuutta etsimässä - irtiottoa keskinkertaisuudesta“ ajautuksille (H eikkilä-Laakso \& H eikkilä 1997). $\mathrm{N}$ ämä seminaarit ovat avoimia myös alueen muille pk-yrityksille.

Projektin kaksi vastuuhenkilöä toteuttavat yrityskohtaista koulutusta. Ne lähtevät kunkin yrityksen omista lähtökohdista ja ovat toteutukseltaan hyvin erilaisia. K oulutuksessa pyritään määrätietoisesti tukemaan tiimien rakentamisprosessia siten, että erilaisuus on voimavara; monenlaiset näkökulmat ja erilaiset persoonallisuudet ovat tiimien vahvuus. Tiimin rakentamisprosessia rakennetaan yhteisen tarkoituksen, yhteenkuuluvuuden ja itsensä tuntemaan oppimisen näkökulmasta (A dair 1983, Fraser \& N eville 1993, Moxon 1993). Yhteistä tarkoitusta rakennetaan pohtimalla pienryhmissä ja yhteisesti tiimin tavoitteita ja niiden taustalla olevia yhteisesti hyväksyttyjä arvoja. Y hteenkuuluvuuden tunnetta lisätään työskentelemällä yhteistä päämäärää kohti vuorovaikutuksessa eri yksilöiden välillä ja arvioiden tiimin työskentelyä. Itsensä tunteminen vahvistuu tiimin jäsenten persoonallisuudesta johtuvia avainosaamisia kartoittaen ja hyödyntäen.

K oulutukset rakentuvat yhteistoiminnallisiin työskentelytapoihin, jäsenten näkemysten kartoitukseen ja niistä nousevien erilaisten näkökulmien avoimeen pohdintaan. Teorialuennot, niiden tulkinta tiimin jäsenten ja yrityksen näkökulmasta sekä tiimitaitojen, erityisesti kommunikointitaitojen kehittäminen ovat osa koulutusta.

\section{Huipputiimin rakentamisen näkökulmia}

Tiimi voidaan määritellä pieneksi ryhmäksi ihmisiä, joilla on toisiaan täydentäviä taitoja, jotka ovat sitoutuneet yhteiseen päämäärään, yhteisiin suoritustavoitteisiin ja yhteiseen toimintamalliin ja jotka pitävät itseään yhteisvastuussa suorituksestaan. (K atzenbach \& Smith 1993) H yvin toimivassa huipputiimissä tarvitaan kaikkien jäsenten monisuuntaista ja monisyistä yhteistyötä. Jäsenten tulee sietää erilaisuutta eikä tule tuhota sitä. (H eikkilä-L aakso \& H eikkilä 1997)

Creatiimi-projektissa toisiaan täydentävät taidot ovat paitsi ammatilliset osaamiserot, erilaiset kokemustaustat, myös tiimien jäsenten persoonallisuuden orientaatioiden erilaisuutta vahvuutena käyttävä näkökulma. Tuolloin tiimi rakentuu erilaisista yksilöistä, jotka eroavat toisistaan orientoitumisessa elämään orientoitumiseen, ulkoisen maailman havaitsemisessa sekä tavassa tehdä päätöksiä. N ämä pohjautuvat Carl G. Jungin havaitsemiin persoonallisuuspreferenssien eroihin, joita Myers-Briggs sovelsi ja joihin lisäsi neljännen ulottuvuuden, orientoitumisen ympäristöön. $\mathrm{N}$ äiden pohjalta ovat H eikkilä-L aakso \& H eikkilä (1997) kehittäneet luovan ja innovatiivisen tiimin rakentamisen avaintekijöitä, jotka ovat Creatiimi-projektin tiimien rakentamisen perusajatuksia.

Huipputiimin rakentaminen on pitkä, vuosia kestävä prosessi, jossa voidaan erotella erilaisia vaiheita. U seat tutkijat (mm. Moxon 1993, E ales-W hite 1996, F raser \& N eville 1993, Skopec \& Smith 1997) ovat kehittäneet Tuckmanin (1965) ajatuksia ja arvioivat tiimin kehittymistä yksilöiden vuorovaikutuksen ja yhteisen tehtävän suorittamisen kannalta. Tiimin työskentelyn alussa (forming vaihe) käsitellään neutraaleita asioita ja vältetään vastakkainasettelua. Seuraavassa vaiheessa (stormingvaihe) yksilöiden väliset konfliktit ja voimakkaat tunteet heikentävät tiimin tavoitteellista toimintaa. Y hteisesti hyväksyttyjen normien muodostuminen sekä toisten näkökantojen arvostaminen ovat luonteenomaisia tiimin seuraavassa vaiheessa (norming vaihe). Tavoitteena oleva korkean suoritustason huipputiimi (performing vaihe) pystyy luoviin ja innovatiivisiin ratkaisuihin. Se jakaa keskenään tehtäviä, jonka mah- 


\section{UTAKOUUTUESTA}

dollistaa kypsyys ja keskinäinen kunnioitus. Tiimissä tunnistetaan toisten vahvuudet ja roolit, ja suuri yhteenkuuluvuuden tunne ja lämpimät suhteet toisiin tiimin jäseniin takaavat suuntautumisen yhteisiin tavoitteisiin. Huipputiimissä on myös yksilöllä mahdollisuus sekä ammatilliseen että persoonalliseen kasvuun.

H yvin toimivalla tiimillä on visio, joka tukeutuu yhteisesti rakennettuun arvopohjaan. Siitä muodostuneisiin selkeisiin tavoitteisiin ovat kaikki sitoutuneet. Tiimillä on avoin ja toisiaan tukeva kommunikaatiokulttuuri, jossa rakentavan palautteen merkitys on suuri. Se pystyy arvioimaan kriittisesti omaa toimintaansa ja sillä on halu toimintansa kehittämiseen reflektoimalla kriittisesti kokemuksiaan. Tiimissä vallitsee toisten inmisarvoa kunnioittava ilmapiiri, jossa kukaan ei käytä valtaa omien etujensa ajamiseen, vaan jossa on interdependentkulttuuri, keskinäisen yhteistyön kulttuuri. Sillä on joustavat toimintamallit ja voimakas yhteenkuuluvuuden tunne. Tiimissä on tilaa tunteille ja tunnustuksen jakamiselle. (mm. H eikkilä-L aakso \& H eikkilä 1997, Colenso 1997, Parker 1990, Skopec 1997)

\section{Projektin kokemuksia}

Creatiimi-projektin toiminta käynnistyi syksyllä 1997. K antavia ajatuksia on se, että koko toiminta lähtee yritysten tarpeista, on prosessinomaista ja etenee avoimessa vuorovaikutuksessa yritysten kanssa.

Mukana on seitsemän eri toimialan yritystä, jotka ovat kooltaan ja myös tiimien tavoitteiden suhteen hyvin erilaisia. Tiimin rakentaminen ja sen seurauksena myös itse prosessi on eri yrityksissä hyvin erilainen. K olmessa yrityksessä tiimin muodostaa koko yrityksen henkilökunta. K aksi yritystä ovat pieniä (alle 10 henkilöä), joten on hyvin luonnollista toimia tällä tavoin. Y hdessä yrityksessä (henkilökuntaa 15) projekti tukee yrityksen toimintanäkemystä, jonka mukaan yrityksen vahvuus on sen henkilökunta. Jokaisen yksilön kasvu lisää yrityksen potentiaalisia mahdollisuuksia. Y rityksen koko henkilökunta osallistui projektin alussa persoonallisuuden kartoitukseen aiemmin mainitun $M$ yers-Briggsin teorian pohjalta. Se on antanut mahdollisuuden muokata toimenkuvia näin esiinnousseita vahvuuksia hyväksikäyttäen sekä pohtia aidosti erilaisuuden merkitystä työyhteisössä. Tekemäni henkilökuntahaastattelu osoitti, että työntekijöiden mielestä tämä lähtökohta oli parantanut työyhteisön tiedonkulkua ja lisännyt avoimuutta. Heidän mielestään yhteinen kokemuspohja mahdollistaa asioiden nopean viemisen osaksi yrityksen arkitoimintaa. Merkittävää oli myös se henkilökunnan kokemus, että vahva teoriapohja ja terävät luennot herättävät ajatuksia ja auttavat löytämään ratkaisuja tiimin kehittymisen, tiimitaitojen omaksumisen että myös yksilöllisen kasvun kysymyksiin.

$\mathrm{K}$ ahdessa yrityksessä (henkilökuntaa 30-40 henkilöä) on rakennettu yrityksen kehittämistiimi, jonka tavoitteena on pohtia kehittämismahdollisuuksia siten, että jokapäiväisessä työnteossa mukana olevat inmiset ovat sekä ideoimassa että toteuttamassa kehittämishankkeita. Tällöin tiimi on koottu mahdollisimman erilaisista tehtävistä ja erilaisen kokemuksen omaavista yksilöistä. Koko yrityksen henkilökunta on yhdessä pohtinut tiimin rakentamisen periaatteita sekä yhdessä valinnut henkilöt tiimeihin. Prosessin edetessä on koettu tärkeäksi pohtia, miten koko henkilöstö voi kokea tiimin yritystä kehittäväksi inmisryhmäksi.

K ahdessa yrityksessä on toimitusjohtajan ja creatiimi-projektin henkilöiden yhteispalaverissa pohdittu niitä tavoitteita, joita koottavalla tiimillä on. Sen perusteella on yritysjohtaja valinnut ne henkilöt, jotka toimenkuvaltaan parhaiten sopivat tiimin keskittymiin kehittämishankkeisiin. Tässä vaiheessa on kuitenkin pohdittu erilaisuuden merkitystä, ja pohdittu ratkaisuja myös siltä kannalta. N ämä yritykset ovat niin suuria (40 ja 230 henkilöä) tai toimivat fyysisesti eri kohteissa, että tällainen lähtökohta tuntui sopivalta.

K oulutustilaisuuksia on yrityskohtaisesti ollut 3-8 kertaa riippuen siitä, paljonko yrityksellä 


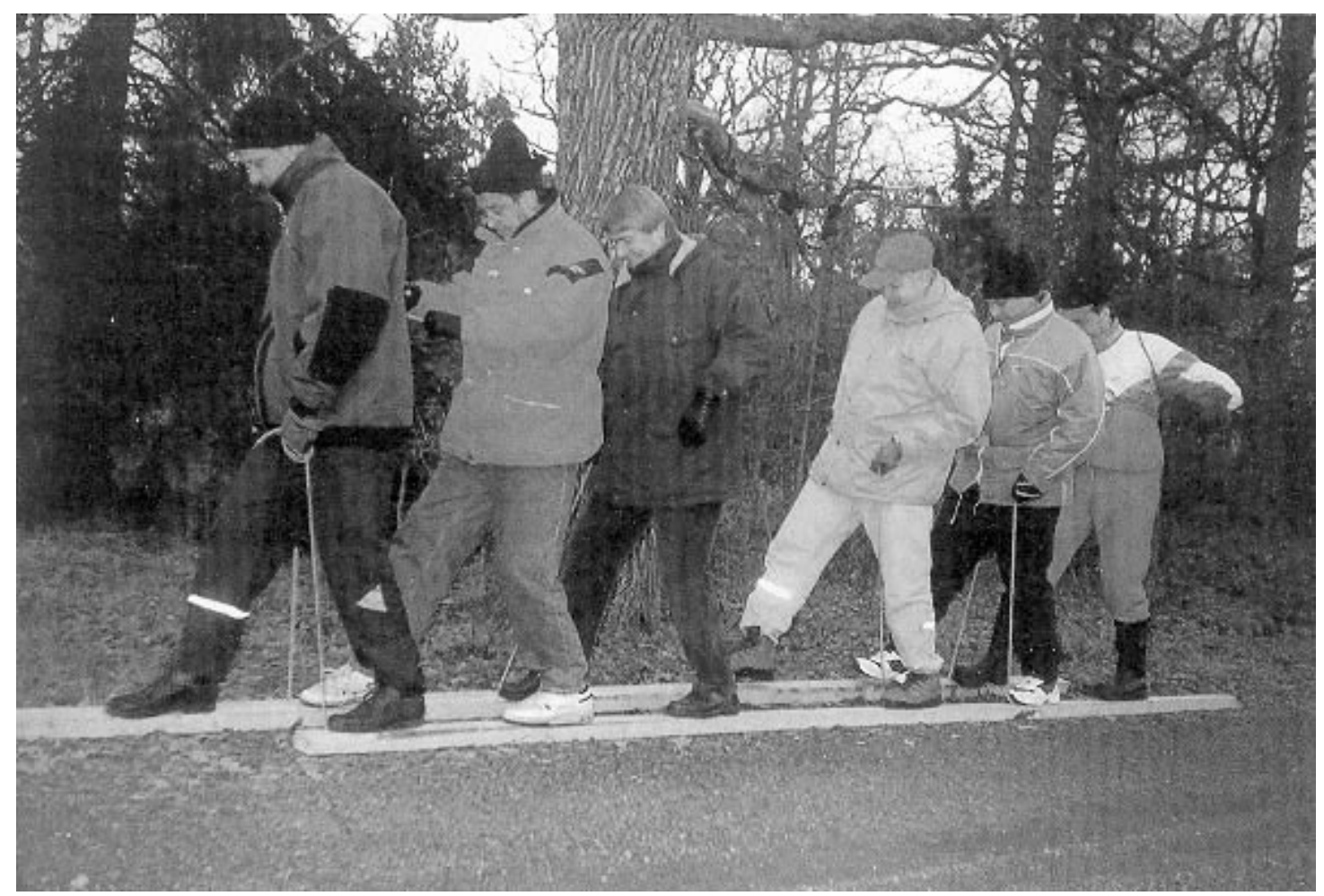

Koulutus toteutetaan eri tavalla eri yrityksissä ja sisällöissä otetaan huomioon yritysten erityispiirteet. Yhden yrityksen johtaja on vanha partiolainen, joten johto sito utui tiimivalmennukseen $\mathrm{mm}$. tällaisin yhteishengen ja yhdessä ratkaisunetsinnän kautta.

on ollut mahdollista löytää kaikille tiimin jäsenille sopivaa yhteistä aikaa. Tiimiin valittujen henkilöiden yhteisen ajan löytäminen on projektin etenemisen kynnyskysymys. Ne yritykset, joissa on mahdollista keskeyttää työt, ovat tässä suhteessa helpommassa asemassa.

K oulutustilaisuudet ovat toteutusratkaisultaan hyvin erilaisia. M iesvaltaisen, insinööripainotteisen yrityksen tiimin rakentamisprosessi aloitettiin koko päivän seikkailulla luonnossa, missä yhdessä ratkottiin erilaisia ongelmatehtäviä. $\mathrm{K}$ aikkiin ratkaisuihin tarvittiin jokaisen tiimin jäsenen mukanaoloa, jotta tehtävässä voitiin onnistua. Päivän aikana tiimin jäsenet loivat mehenkeä, halua mennä hdessä eteenpäin. Sen lisäksi rakennettiin tiimille yhteistä arvopohjaa, mistä yhteiset tavoitteet lähtevät. Tämän kokemuksen innoittamana on ollut mahdollista läh-

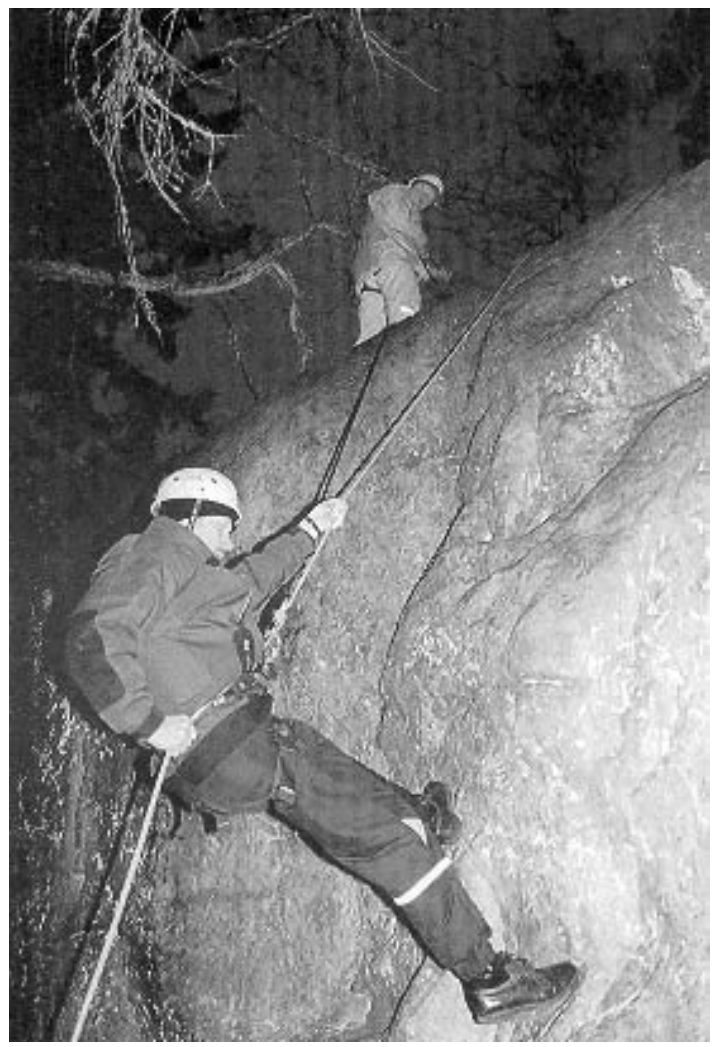




\section{UTAKOUIUKSTA}

teä pohtimaan strategioita yhteisten tavoitteiden saavuttamiseksi.

Joissakin mukana olevista yrityksissä on tiimin rakentamisprosessi alkanut yhteenkuuluvuuden luomisella toisiin jäseniin tutustumalla ja keskustelemalla yhteisistä asioista aluksi pienryhmissä. Sen jälkeen on yhdessä pohdittu tiimin tavoitteita. O n mietitty myös niitä taitoja, joita tarvitaan, jotta tiimi kehittyy uusia ideoita tuottavaksi. O n kiinnitetty huomiota omaan toimintaan.

Creatiimi-projekti korostaa prosessia. K ussakin yrityksessä tämä prosessi on toimintatavoiltaan ja myös tuloksiltaan erilainen. Tavoitteena on kahden vuoden aikana rakentaa yrityksiin luovia ja innovatiivisia tiimejä ja tukea niiden toimintaprosesseja. Samalla pyritään luomaan yrityksiin tiimiorientoitunut, itseohjautuvasti toimiva johtamis- ja toimintakulttuuri.

Projektin kouluttajat oppivat itse myös koko ajan. Y ritysten "todellisessa" elämässä mukanaolo laajentaa omaa näkökulmaa. K oulutustilaisuudet tulee toteuttaa siten, että rajallista aikaa käytetään yrityshenkilöstön motivoimiseen ja tiimin kehittämisen kannalta muutenkin tehokkaasti. Samalla on mahdollisuus aistia niitä tarpeita, joita tämän päivän yrityksissä tarvitaan. Jo nyt on osoittautunut, että on tarvetta "tiimitaitojen" oppimiselle. N e ovat taitoja, kuten monet muutkin, joita yhdessä pohtien voidaan kehittää. K ommunikaatiokulttuurin kehittäminen on eräs suurimpia tehtäviä.

\section{Tiimityöskentelyn toteuttamisesta projektin kokemusten valossa}

Lyhyen kokemuksen puitteissa on ilmennyt seuraavanlaisia seikkoja, jotka osaltaan vaikuttavat siihen, miten tiimimäinen toimintakulttuuri leviää yrityksissä:

- $\quad$ Yrityksissä on halua kehittää tiimityöskentelyä, mutta monelta yritysjohtajalta puuttuvat konkreettiset "työkalut", jolla prosessia viedään eteenpäin. Tiimin rakentaminen erilaisuutta arvostavaksi eikä sitä tuhoavaksi vaatii tietoa tiimin toiminnassa huomioon otettavista seikoista. Siksi tuntuu mielekkäältä yhdistää yliopistollista osaamista, tässä tapauksessa Turun opettajankoulutuslaitoksen osaamista, sekä yrityksen oman henkilökunnan tietotaitoa heidän to dellisuudestaan.

Toimintakulttuurin muutos on aina eräänlainen kehitysprosessi, joka ainakin prosessin aluksi vaatii selvää keskittymistä, aikaa pysähtyä ajattelemaan. Tulee yhdessä muodostaa "tahtotila", halu kehittää. Pitää yhdessä synnyttää ajatus siitä, että kehittäminen on tarpeellista, ja etsiä yhdessä uusia mahdollisuuksia. Suurimpana ongelmana on löytää yrityksistä aikaa "pysähtyä" jokapäiväisestä työnteosta ja keskittyä tiimin rakentamisprosessiin.

- Miten saada inmiset oivaltamaan se, että toimivan tiimin rakentaminen on prosessi, joka ei synny hetkessä. O n ymmärrettävää, että yritys ja henkilökunta odottavat tuloksia nopeasti, mutta luottamuksellisen ja avoimen kommunikaatioilmapiirin luominen vie aikaa.

Tiimin jäsenten sitoutumista edesauttaa, jos koko yrityksen henkilökunta on mukana prosessissa tai tietoinen tiimin toiminnasta. $N$ äin ainakin silloin, kun kyseessä on henkilöstön oman toiminnan ja toimintaympäristön kehittäminen.

Projektin kuluessa on havaittu, että yrityksen todellisuus lähtökohtana motivoi inmisiä sekä mahdollistaa konkreettisia, vaikka pieniäkin tuloksia. Tällöin saadaan nopeasti aikaan joitakin muutoksia, ja inmisillä säilyy halu jatkaa kehittämistä.

- $\quad$ Y ritysjohdon sitoutuminen projektiin on tärkeää. Hänen osallistumisensa ainakin osittain koulutustilaisuuksiin sekä aktiivinen panoksensa prosessin kehittämisessä edesauttavat prosessin kehittymistä.

- Y Yrityksen johdolla tulisi olla selkeä näkemys siitä, mitä tiimityöllä odotetaan saavutettavan. Tiimityö edellyttää lisäksi vanhojen toimintamallien poisoppimista ja uuden toimintakulttuurin kehittämistä. 0 nnistuneiden tiimien avulla yritys kykenee lisäämään ongelmanratkaisukykyä, innovatiivisuutta ja luovuutta. Se pystyy joustavammin reagoimaan toimintaympäristön muutoksiin. 
Myös tiimi-käsitettä joudutaan selkeyttämään. Se on muotisana, jonka merkitys on hämärä. Mitä tiimillä tarkoitetaan? Miten tiimi kootaan ja mikä on tiimin tarkoitus? Miten tiimi eroaa ryhmästä, mitkä ovat sen "pelisäännöt"?

Miten voidaan oppia tiimissä toimimisen taitoja? Miten tiimissä voidaan käyttää erilaisuutta voimavarana? Miten yritysten johtamiskulttuuria tulee muuttaa, jotta tiimissä työskentelyllä on todellinen merkitys?

H yvin toimiva tiimi vaatii rakentamista, ja tämä prosessi on pitkä ja takkuinenkin. Siitä huolimatta se kannattaa, sillä se on eräs keino antaa yritysten ihmisille mahdollisuuksia kasvaa persoonina, oppia muilta tiimin jäseniltä ja kokea itsensä arvostetuksi omana itsenään. Tiimissä toimiminen antaa työyhteisössä toimiville ihmisille mahdollisuuksia vaikuttaa. Tiimillä voidaan myös tukea henkilöstön jaksamista. Yhdessä tekeminen ja erilaisuuden hyväksyminen ovat tämän päivän yhteiskunnassa ja menestyvässä yritysmaailmassa avaintekijöitä. Näin yhdessä voidaan proaktiivisesti aistia tulevia haasteita, sen sijaan että retroaktiivisesti reagoidaan muutoksiin. Sillä suurin riski tämän päivän maailmassa on se, ettei ota riskiä lainkaan, vaan jää paikalleen.

\section{Miten tästä eteenpäin}

Creatiimi- projektiin liittyi tänä keväänä neljä uutta yritystä. Uusien mukaan lähtevien yritysten tuli sitoutua löytämään noin kerran kuukaudessa tiimin jäsenille yhteistä aikaa kehittääkseen toimintaansa Creatiimin kahden projektihenkilön tuella.

O lemme myös oppineet, että tiimin rakentaminen ei itsessään voi olla tavoite, vaan hyvin toimiva tiimi on hyvä keino yritysten moniulotteisten kehittämishankkeiden toteutukselle.
Y rityksen omien haasteiden toteuttaminen siten, että samalla tuetaan tiimimäisen toimintakulttuurin omaksumista, on monialaisia näkemyksiä toteuttava vaihtoehto. Tiimityöskentelytaitojen oppiminen ja huipputiimin rakentamisprosessin vaatima pitkä aika edellyttävät yhteistä pohtimista, miten prosessia voidaan ajoittain tukea. Hyvät artikkelit ja ajatuksia herättävät tehtävät ovat nousseet esille joissakin yrityksissä mahdollisuutena tukea prosessin etenemistä.

Lisäksi tulee pohtia, miten alkuun saatettu toiminta jatkuu itseohjautuvasti projektin päätyttyä. Y ritysjohdon kiinnostus kehittämistiimien toiminnasta on osaltaan tukemassa yrityksen toimintakulttuurin kehittämistä kohti dynaamista, joustavaa organisaatiota.

\section{Lähtet}

ADAIR, J. (1986) Effective teambuilding London: Pan Books.

COLEN SO, M. (1997) High peforming teams in brief. London: Butterworth-H eineman.

EA LE S-WHITE, R (1995) Building Your Team London: $K$ ogan Page.

FRASER, A.\& N eville, S. (1993) Tem building London: Cromwell Press.

HEIK KILÄ, J. (1994). Turun opettajankoulutuslaitos oppivana organisaationa. Teoksessa Tähtinen, J. (toim.) Opettajaksi kastaminen. Turun opettajankoulutuslaitoksen linjojen hahmottelua. Turun yliopiston kasvatustieteiden tiedekunnan julkaisusarja B:46, 163-181.

HEIK KILÄ-LAAK SO, K. (1994) E räs tapa lähestyä opettajaperso onallisuutta. Teoksessa Tähtinen, J.(toim.) Opettajaksi kastaminen. Turun opettajankoulutuslaitoksen linjojen hahmottelua. Turun yliopiston kasvatustieteiden tiedekunnan julkaisusarja B:46,92-113.

HE IK K ILÄ-LAAK SO, K - H eikkilä, J. (1997) Innovatiiiusuutta esimässä. Irtiatto keskinketaisuudesta. Tu run yliopiston kasvatustieteiden tiedekunnan julkaisusarja B:57.

KATZEN BACH, J.\& Smith, D.(1993) Tiimit ja tuldkse kas yritys Jyväskylä: Weilin $\& G$ öös.

M OXON, P.(1993). Building a Better team A handbook for managrs and failitators. London: G ower Books.

PARKER, G.(1990) Team players and teamuork. San F rancisco: Jossey-Bass Inc.

SK O PEC, E.\& Smith, D. (1997) Practical Exeative and Tæm Building London: Business Books.

TUCKMAN, B (1965) Developmental Sequence in Small Groups. Psychological bullein 63,6,384-399. 